\title{
Female Executives Leadership on Non-Efficiency Investment of Private Listed Companied in China
}

\author{
Mengyi Fan ${ }^{1}$, \& Wasin Phromphitakkul ${ }^{2}$ \\ ${ }^{1} \mathrm{PhD}$ Candidate, Management, School of Management, Shinawatra University, Thailand \\ ${ }^{2}$ School of Management, Shinawatra University, Thailand \\ Correspondence: Mengyi Fan, Management, School of Management, Shinawatra University, Thailand. \\ Wasin Phromphitakkul, Management, School of Management, Shinawatra University, Thailand.
}

Received: January 25, 2021

Accepted: February 25, 2021

Online Published: February 26, 2021

doi:10.5539/ibr.v14n3p53

URL: https://doi.org/10.5539/ibr.v14n3p53

\begin{abstract}
The purpose of this paper is to study the relationship between female executives and non-efficient investment behavior in enterprises. The data of China's private listed companies from 2016 to 2017 were selected for empirical study, the variables of the model were defined and measured. The author designs the current research to be mixed methods research, qualitative and quantitative research approach. The results show that: (1) increase in the proportion of female CEOs relative to female executives can significantly inhibit non-efficient investment; (2) the level of education has a significant moderating effect on both female executives and the non-efficient investment of female CEOs and companies; (3) Social capital has a moderating effect on the non-efficient investment of female executives and enterprises, but has no significant effect on the gender of CEOs and non-efficient investment of enterprises. The conclusion of this study can better break the bottleneck of female workplace, develop the leadership of female executives in a targeted way, and improve the management level and performance of enterprises through the relationship between female executives and non-efficient investment behaviors of enterprises.
\end{abstract}

Keywords: female executives, private listed companied, non-efficiency investment

\section{Introduction}

From the macroeconomic point of view, investment is an important factor to promote the overall economic development. For a single company, investment is the foundation of the company's future cash flow growth, and the level of investment efficiency directly affects the growth of the company. In real life, Chinese companies have a large number of non-efficient investment behaviors: some managers blindly invest funds in so-called "hot" industries, forming excessive investment; Some managers have insufficient investment and are bound by financing and cannot obtain sufficient funds. Both of these phenomena have damaged the interests of investors and caused a waste of resources. This kind of waste of resources is called non-efficient investment.

From the foreign research on the relationship between female executives' leadership and the non-investment efficiency of enterprises, in addition to the fact that there is no relationship between female executives and the non-investment efficiency of enterprises, the majority of female executives are generally considered to have a significant impact on the non-investment efficiency of enterprises through their own decisions. However, most of these studies are carried out in the western context. Due to the particularity of China's social and political background, it is of great significance to study the leadership of female executives in private enterprises and the non-efficient investment behavior of enterprises in this context.

\subsection{Research Purposes}

There are three main research purposes in this article.

1. From the perspective of the executive team and individuals, try to find out the relationship between the leadership of female executives and the non-efficient investment behavior of the company.

2. From the two perspectives of human capital and social capital, to study the role of human capital and social capital in the leadership of female executives and the non-efficient investment behavior of enterprises.

3. To provide certain reference suggestions for optimizing the senior management team. 
4. On the basis of the previous research, to provide a certain basis for listed companies to improve investment efficiency, and find reasonable suggestions for private enterprises to improve their decision-making level.

\section{Literature Review}

\subsection{Related Theory}

\subsubsection{Enterprise investment theory}

Theory of western investment in booming rapidly between 1930-1970, formed a relatively complete system, in the period to form the rich theoretical knowledge and genre, especially to the Keynesian school and new classical investment theory represented by the investment theory of western investment theory research results reached the apex of development, has made brilliant achievements.Up to now, in the western relatively influential economics subject teaching material, or takes Keynes investment theory, the neoclassical investment theory as the main teaching reference.Keynesian investment theory originated in 1930, based on the investment ideas in Keynes' General Theory of Employment, Interest and Money, and further deepened by Keynes's followers.Based on the effective demand of investment, Keynesian investment theory points out the relationship between the marginal efficiency of capital and interest rate. Investment and interest rate are negatively related, and positively related to the marginal efficiency of capital. But as time goes by, more and more economists believe that the factors affecting investment efficiency can not be determined simply by the marginal efficiency of capital and the level of interest rates, but also need to consider other factors.

\subsubsection{Principal-Agent Theory}

Ross (1973) was the first to define the modern principal-agent relationship: "The generation of the principal-agent relationship is because the company's agent can perform certain decision-making powers on behalf of the principal's interests."The separation of corporate ownership and control directly leads to conflicts between shareholders and managers. Jensen (1986) further explained the conflict between shareholders and managers. He believes that the purpose of shareholder management is to maximize the value of the enterprise and create more wealth for them, while managers will harm the interests of the enterprise for the privatization of interests.In addition to the resources and the reasons of on-the-job consumption, another explanation is that the project managers chose is negative, is to raise their capital, managers to highlight its advantages and skills, not from the optimization goal of enterprise, but too much emphasis on the development of the company, thus improve the company for its dependence, forming self protection. There is also a view that managers tend to underinvest, as opposed to overinvest.Such managers tend to be more conservative and risk averse in their investment. They seek no merit but no fault. This instinct of risk aversion runs counter to the interests of managers and shareholders, and will be shown as underinvestment when making investment.

\subsubsection{Free Cash Flow Theory}

Jensen (1986) put forward the theory of free cash flow. This theory believes that the corresponding agency cost is caused by capital flow due to the interest issues and consulting differences between the company' $\mathrm{s}$ stockholders, corporate leaders, and senior management. Company leaders and senior managers can use capital flows to participate in some high-return projects to meet their own interests, and have a tendency to overinvest in the establishment of a "manager empire". This kind of motivation encourages managers to use more disposable corporate internal funds for corporate project investment.

\subsubsection{Information Asymmetry}

The existence of asymmetric information is an objective factor that affects the non-efficient investment of enterprises. Myers(1984)found that when an enterprise's external financing is higher than its internal financing, it is more likely to cause underinvestment. When the company conducts financing, due to the existence of information asymmetry, the stock price may be overvalued or undervalued. If the stock is undervalued, the loss will be greater than the benefit of investment, and the company will choose to give up the investment project with positive NPV, resulting in the behavior of underinvestment. On the contrary, if stocks are overvalued, companies will be willing to issue more shares, or even use the funds raised for investment projects with a net present value less than zero, resulting in blind investment.

\subsubsection{Theory of Resource reliance}

Pfeffer and Salancik (1978) was the first to put forward his opinion on the resource dependence theory, and they all said the organization to continue its own survival and development, must be obtained from the open environment, the resource needed or exchanged with specific resources and environment, organization's ability to obtain and maintain resources determines the organization's survival or not, and the organization of the key is 
to keep good relationship with important resource provider, so as to improve enterprise value. As a unique resource of enterprises, senior executives play an irreplaceable role in enterprises. Executives as managers of enterprises, can bring resources for enterprises from the following three aspects: - provides environment and competitors' information, and provide strategic and operating from the Angle of professional technical support; Create good internal and external information communication channels for enterprises; Make the behavior of the enterprise in the external environment more legitimate, so as to help the enterprise can more easily obtain support from the resource providers in the external environment.

\subsubsection{Overconfidence Theory}

The theory of overconfidence proposed at the end of the 20th century originated from the theory of behavioral finance, and one of the important research results of cognitive psychology is also "overconfidence". A large amount of cognitive psychology literature believes that people are overconfident in the accuracy of their knowledge, thus overestimating their probability of success and underestimating the probability of failure in decision-making (Wolosin et al., 1973).Researches by domestic and foreign scholars have also shown that male executives are more likely to be overconfident than female executives. (Zuckerman, 1994) Huang and Kisgen (2013) compared the differences in corporate financial decisions and investment decisions made by different executive genders, and found that male executives made acquisitions and issued debt more frequently than female executives. In addition, the announcement of acquisitions and debt issuance of companies where female executives are located is more profitable, leading to the conclusion that male executives are more overconfident than female executives. Combining the above theories, female executives are less likely than male executives to develop overconfidence. When the free cash flow is sufficient, they will not overestimate the project profit or underestimate the project financing cost, thus inhibiting the overinvestment of enterprises. In the absence of free cash flow, there will be no underinvestment phenomenon.

\subsection{Research on Enterprise Non-Efficient Investment}

Heaton (2002) From the financial perspective, the free cash flow is the most measured standard, and the free cash flow and overconfidence are combined to study. The results show that under different free cash flows, overconfident managers can easily make non-efficient investment decisions. Grenadier \& Wang (2005) found that some managers are more likely to reduce investment after the privatization of economic costs, resulting in underinvestment, Under the condition of information asymmetry, managers' investment behavior has the characteristics of rapidity or delay, principal-agent causes managers to maximize their own interests and obtain greater value through excessive investment. Based on the study of the relationship between promotion incentives and over-investment (Zhang Zhaoguo et al.2013), the study found that in state-owned and non-state-owned companies, managers with different background characteristics also have different effects on promotion and over-investment.

\subsection{Research on Female Executives and Investment Behavior}

Appold (1998) found Compared with men, female executives are more willing to delegate power and provide information to subordinates and grass-roots employees, which to a certain extent helps to mobilize the enthusiasm of the majority of employees. Through such a feedback mechanism, employees will then convey a large amount of corporate information to them, thereby decision-making is more reasonable and effective. Peng (2007) conducted a survey of stock companies in the United States from 1998 to 2003 that mainly had women as CEOs and found that when making investment decisions, female executives were more sensitive than male executives in terms of cash flow. The research of Hillman et al.(2007)also points out that female directors are always related to factors such as enterprise organizational scale and industry type. Compared with male executives, female executives have different innate characteristics, and the differences in these innate characteristics will lead to their different attitudes and behaviors from male executives. For example, women are careful and prudent, sensitive and good at communication, which helps to resolve team conflicts and promote harmonious coexistence among team members. Huang Xu et al. (2013)used listed manufacturing companies as the research object to empirically test the relationship between relevant background characteristics of executives and corporate mergers and acquisitions. The higher the proportion of women in the senior management team, the greater the risk of corporate mergers and acquisitions.

\subsection{Research on the Impact of Female Executives on Company Performance}

Female executives can provide diverse perspectives and innovative solutions for management decision-making, diversify the executive team, and match the diversity of customers and employees, bringing more internal support and external resources to the company. Agrawal and Knoeber (2001) found in their research that executives with legal and political backgrounds were more willing to work in companies that pay attention to 
political relations because they had scarce political resources. The participation of such executives also further improved corporate performance. Welbourne (1999) uses TobinQ to measure the short-term performance of enterprises, using the company's three-year stock price growth as a measure of long-term performance, it is found that the improvement of a company's performance is mainly due to a higher proportion of female executives. Luca Flabbi et al. (2012) took Italian manufacturing companies as a sample. He controlled the wage and promotion gap between men and women and got the result, female executives do have a relationship with corporate performance. It is further discovered that companies with female CEOs make the society realize that the company has a stronger sense of social responsibility and can help the company gain more recognition and support from the society, thereby obtaining more social resources, promote enterprise investment efficiency and improve enterprise performance. However, there are also studies that believe that the performance of companies run by women is lower than that of men. Rosa et al. (1996) took the gender of small business owners as the research counterpart and found that the relationship between gender and corporate performance is extremely complex. It is found that men are more expansive than women, and that male entrepreneurs are more capable of taking care of themselves and have more resources and assets. These factors have led to the fact that the performance of female entrepreneurs is significantly lower than that of men.

Through literature review, it is found that the presence of female executives has a significant positive impact on corporate performance, which is a mainstream view in existing research and has also been widely recognized and supported. This is also the main basis for the current governments to force companies to increase the proportion of female executives.

\subsection{Literature Commentary}

Based on the existing literature review, we found that:

1. The existing literature focuses more on the relationship between the background characteristics of executives and corporate performance, and less on investment efficiency. Investment decision-making is one of the important transmission mechanisms or "intermediate bridges" that affect corporate performance. In fact, the leadership of corporate executives first affects corporate investment and financing decisions, pricing decisions, and diversification decisions, and then affects corporate performance (Xin Qingquan et al., 2007).

2. Principal-agent, information asymmetry, etc., as the hot spots of previous studies, are mainly based on the rational assumption of managers. Regarding the impact of managers' irrational behaviors, the academic community has not yet given a definite answer, and because managers need to consider factors when they perform irrational behaviors, the academic community has not yet reached a unified conclusion. Most of the existing literature on the research of female executives and investment behaviors of enterprises tend to believe that the personality characteristics of women determine their performance in investment behaviors. It is generally believed in the academia that women are cautious and conservative, while some scholars believe that women are more aggressive than men.

3. China's research on non-efficient investment is mainly based on the results of Western research, but whether the Western results are suitable for China's national conditions is also a development direction for Chinese scholars on non-efficient investment research. Due to the particularity of the Chinese institutional background and the influence of traditional concepts, in state-owned enterprises, owners and managers are separated, and those who have the right to operate are not shareholders in the true sense, the agency problem between shareholders and managers is more serious than that of private enterprises. Moreover, private enterprises aim at chasing profits. They are unwilling to be interfered by the government, and their decisions are more scientific. Therefore, it is of great significance to study the leadership of female executives of private enterprises and thenon-efficient investment behavior of enterprises in this context.

\section{Research Hypothesis}

This section is based on the conceptual model, combined with the high-level echelon theory and the resource-dependent theory, fully considering the impact of China's economy and social culture, discusses the human resources and social resources as the moderating variables, analyzes the relationship between female executives and non-efficient investment of enterprises, and puts forward the following hypotheses.

H1 The higher the proportion of female executives in the senior management team, the lower the level of non-efficiency investment.

H2 The higher the average level of education, the lower the level of non-efficiency investment of companies with higher proportion of female executives.

H3 The higher the proportion of social capital, the lower the level of non-efficiency investment of companies 
with higher proportion of female executives

H4 Companies with female CEO invested less in non-efficiency than those with male CEO

H5 The more educated the female CEO, the lower the level of non-efficiency investment

H6 The social capital of female CEO will increase the level of non-efficiency investment of companies

\section{Research Methodology}

Since the current research focuses on the impact of the special perspective of female executives on the Non-efficient Investment behavior of private listed companies, the data and information from primary source of data is crucial. The author needs to have both wide and deep information from such sources. Thus, to fulfill the requirement of wide and deep data, the author designs the current research to be mixed methods research, Research methods include a Combination of normative research and empirical research, statistics combined with mathematical models and the qualitative and quantitative research approach.

\subsection{Data Collecting Method}

All data in this article comes from Wind database and CSMAR database. In sample selection, the main research objects are private listed companies in Shanghai and Shenzhen. In order to ensure the stability and validity of the sample data, this article makes the following data processing based on the original data:

a. Exclude newly listed companies, and select private companies listed before December 31, 2015 as the original sample;

b. Exclude companies that were specially treated by ST and *ST in 2016-2017

c. Eliminate cross-holding companies;

d. Exclude financial listed companies;

e. Exclude listed companies whose CEO changes in the research interval;

f. Eliminate missing data and outliers.

In the end, a total of 1409 private listed companies samples from 2016 to 2017 were obtained. This article mainly uses EXCEL 2019 for initial processing of samples and SPSS26.0 for empirical analysis of samples.

\subsection{Data Analysis}

\subsubsection{Non-investment Efficiency}

In order to test the influence of female executives' leadership on the non-efficient investment behavior of private listed companies, this paper analyzes the relevant literature. The model of Richardson(2006), the research of Xin Qingxuan (2007), Yang Dan (2011) and others are used for reference.

Taking all listed private companies in China from 2016 to 2017 as samples, the following equation is adopted to measure the level of npn-efficient investment by separating normal investment expenditure and unexpected investment expenditure. The estimated value of the explained variable in the fitting equation is the normal investment expenditure, and the residualcis the unexpected investment expenditure, which represents the degree of non-efficient investment of the enterprise. The greater the absolute value ofresiduale, the more serious the non-efficient investment of the enterprise.If the residualcis positive, it means overinvestment; if the residual is negative, it means underinvestment.

Inew $=\mathrm{a} 0+\mathrm{a} 1$ Growtht $-1+\mathrm{a} 2$ Let- $1+\mathrm{a} 3$ Cash $\mathrm{t}-1+\mathrm{a} 4$ Aget- $1+\mathrm{a} 5$ Sizet-1 +a6 I new,t- $1+\mathrm{a} 7$ Industry $+\varepsilon$

Equation

In the formula, Inew is new investment, Inew $=$ (capital expenditure $+M \& A$ expenditure-income from the sale of long-term assets- Depreciation)/total assets. Among them, "capital expenditure" comes from cash paid for the purchase and construction of fixed assets, intangible assets and other long-term assets in the direct cash flow statement. "M\&A" is derived from the direct method of cash flow statement, the net cash paid by subsidiaries and other business units. "Income from the sale of long-term assets" is derived from the difference in cash recovered from the disposal of fixed assets, intangible assets and other long-term assets in the direct method of the cash flow statement. "Depreciation" is derived from the depreciation and amortization expense of the indirect method of the cash flow statement. 
Table 4.1. Investment level equation variable definition and measurement table

\begin{tabular}{|c|c|c|}
\hline Variable Symbol & Variable Name & Variable Definition and Measure \\
\hline Growth t-1 & Investment opportunity & $\begin{array}{l}\text { (number of liquid shares*price per stock market }+ \\
\text { number of non-liquid shares*net assets per share }+ \\
\text { book value of negative debt)/book value of total } \\
\text { assets. }\end{array}$ \\
\hline Levt-1 & Asset-liability & Company liabilities/assets at year end \\
\hline Casht-1 & Cash holding level & $\begin{array}{l}\text { Cash and cash equivalents at the end of the } \mathrm{t}-1 \text { year } \\
/ \text { total assets at the beginning of the } \mathrm{t}-1 \text { year }\end{array}$ \\
\hline Age t-1 & Time to market. & $\begin{array}{l}\text { The number of years the company has been listed } \\
\text { as of the end of the previous period. }\end{array}$ \\
\hline Size t-1 & Company scale & $\begin{array}{l}\text { Natural logarithm of company assets at the end of } \\
\text { the t- } 1 \text { year }\end{array}$ \\
\hline Ret $\mathrm{t}-1$ & Earnings per share & t-1year-end earnings per share \\
\hline Inew,t-1 & Last year's investment level & t-1 year investment expenditure \\
\hline
\end{tabular}

\subsubsection{Variables}

Gender is a dichotomous variable coded 1 If there is a female CEO in the company and 0 if a man. The research on the female executive team adopted the proportional method, which is the proportion of female executives in the company's executive team.

Lu Xin et al. (2017) believe that senior executives have higher academic qualifications, use new information, adapt to environmental changes, and have stronger abilities to analyze information, which will help them make correct decisions. Women's human capital (Hcap) refers to women's education level. This article uses the CSMAR database as the standard and encodes it from 1 to 5, where 1 means technical secondary school and below, 2 means junior college, 3 means undergraduate, 4 means graduate student, and 5 means doctor. Regarding the social capital (Scap) of female executives, it mainly starts from the political background and political connections of female executives. Among the female executives, there are not only those who have worked in the government, but also those who have worked in local governments, associations and even the Federation of Industry and Commerce. In this paper, the method of dummy variables is used for measurement, and the ones that have occurred these behaviors are set to 1 , and the others are set to 0 .

Scap $=$ the number of female executives with social capital $/$ total number of executives

Three control variables are added: $\mathrm{CN}$, Outdir and size. The high concentration of stock rights will generate conflicts between large shareholders and small shareholders, which is not conducive to the efficiency of companies. Therefore, this paper selects the first large shareholding ratio as an intermediate measure of equity.

Independent directors provide independent and professional opinions on the company's operation and management in an independent capacity, which can effectively improve the company's operation and management. Therefore, this paper considers that the ratio of independent investment can affect the level of non-efficiency investment of companies.

The smaller the size of the enterprise, the more the investors of the enterprise have expanded their mobilization, and the larger companies may be more bureaucratic so that they will face more resistance when responding to the external environment of the enterprise. In order to avoid adverse effects on the results of the regression analysis, this paper uses the natural logarithm of the number of workers in the measurement of enterprise size variables. 
Table 4.1. definition and measurement of variables

\begin{tabular}{|c|c|c|}
\hline Variable Symbol & Variable Name & Variable Definition and Measure \\
\hline FTM ratio & $\begin{array}{l}\text { Proportion of female } \\
\text { executives }\end{array}$ & $\begin{array}{l}\text { FTM ratio= Number of female executives/total number } \\
\text { of executives }\end{array}$ \\
\hline Fem & Female CEO & Assign 1 when it exists and assign 0 when it does not. \\
\hline Hcap1 & Female's human capital & The average level of education of female executives \\
\hline Hcap2 & $\begin{array}{lll}\begin{array}{l}\text { Female } \\
\text { capital }\end{array} & \text { CEO human } \\
\end{array}$ & $\begin{array}{l}\text { The highest educational level of a manager,Technical } \\
\text { secondary school and secondary school below } 1 \text {, junior } \\
\text { college for } 2 \text {, undergraduate for } 3 \text {, master students for } 4 \text {, } \\
\text { doctoral students for } 5 \text {, other for } 6 \text {. }\end{array}$ \\
\hline Scap1 & Female's social capital & $\begin{array}{l}\text { Number of female executives with social capital / total } \\
\text { number of corporate executives }\end{array}$ \\
\hline Scap2 & Female CEO social capital & Assign 1 when it exists and assign 0 when it does not \\
\hline $\mathrm{CN}$ & Ownership concentration & The shareholding ratio of first major shareholder \\
\hline Outdir & $\begin{array}{l}\text { Proportion of independent } \\
\text { directors }\end{array}$ & $\begin{array}{l}\text { The ratio of the number of independent directors to the } \\
\text { number of directors }\end{array}$ \\
\hline Size & The number of worker & In (total number of employees) \\
\hline
\end{tabular}

\subsubsection{Model Construction}

The sample data in this paper belongs to the cross-sectional data. The SPSS software commonly used in measurement is used for multi-regression analysis.

Step 1: By substituting the value of each financial data into this mathematical model(1), we can get $\varepsilon$ after linear regression

Step 2: The $\varepsilon$ in equation (1) is substituted as $I^{\varepsilon}$ into the other five models to test the hypothesis of regression.

The sample data in this paper are cross-sectional data, and the SPSS software commonly used in measurement is used to conduct multi-element regression analysis. The model is as follows:

ModelI used to test hypotheses 1 and hypotheses 4 :

$$
\mathrm{I}^{\varepsilon}=\alpha+\beta_{1} * \mathrm{Fem}_{\mathrm{ratio}}+\beta_{2} * \mathrm{Fem}+\gamma_{1} * \text { outdir }+\gamma_{2} * \text { size }+\gamma_{3} * \mathrm{CN}+\varepsilon
$$

Model IIused to test hypotheses 2:

$$
\mathrm{I}^{\varepsilon}=\alpha+\beta_{1} * \mathrm{Fem}_{\text {ratio }}+\beta_{2} * \mathrm{Hcap}_{1}+\beta_{3} * \mathrm{Fem}_{\text {ratio }} * \mathrm{Hcap}_{1}+\gamma_{1} * \text { outdir }+\gamma_{2} * \text { size }+\gamma_{3} * \mathrm{CN}+\varepsilon
$$

Model III used to test hypotheses 3:

$$
I^{\varepsilon}=\alpha+\beta_{1} * \text { Fem }_{\text {ratio }}+\beta_{2} * \text { Hcap }_{1}+\beta_{3} * \text { Fem }_{\text {ratio }} * \operatorname{Scap}_{1}+\gamma_{1} * \text { outdir }+\gamma_{2} * \text { size }+\gamma_{3} * \mathrm{CN}+\varepsilon
$$

Model IV used to test hypotheses 5:

$$
\mathrm{I}^{\varepsilon}=\alpha+\beta_{1} * \mathrm{Fem}_{\text {ratio }}+\beta_{2} * \mathrm{Hcap}_{2}+\beta_{3} * \mathrm{Fem}_{\text {ratio }} * \mathrm{Hcap}_{2}+\gamma_{1} * \text { outdir }+\gamma_{2} * \text { size }+\gamma_{3} * \mathrm{CN}+\varepsilon
$$

Model $\mathrm{V}$ used to test hypotheses 6:

$$
I^{\varepsilon}=\alpha+\beta_{1} * F_{\text {ratio }}+\beta_{2} * \operatorname{Scap}_{2}+\beta_{3} * \mathrm{Fem}_{\text {ratio }} * \operatorname{Scap}_{2}+\gamma_{1} * \text { outdir }+\gamma_{2} * \text { size }+\gamma_{3} * \mathrm{CN}+\varepsilon
$$

Among them, $\mathrm{I}^{\varepsilon}$ is the company's inefficient investment, including over-investment and under-investment. $\alpha$ is a constant term, $\beta_{1} 、 \beta_{2}$ and $\beta_{3}$ are the coefficients of the corresponding explanatory variables, $\gamma_{1}, \gamma_{2}, \gamma_{3}$ represent the control variables.

Table 4-1 Investment level equation variable definition and measurement table

\section{Findings and Discussion}

This article first conducts a regression analysis on the proportion of female executives and non-efficient corporate investment (Model I-1), and then conducts a regression analysis on female CEOs and corporate non-efficient investment(Model I-2).Finally, put these two variables in the model for return inspection(Model I-3),to ensure the accuracy of the results. Note: data in the economic management category should be significant at least within the significance level of $10 \%$. 
Table 5.1. Regression analysis of female executives and corporate non-efficient investment

\begin{tabular}{lllllll}
\hline & Model I-1 & & Model I-2 & & Model I-3 & \\
\cline { 2 - 6 } & coefficient & $\mathrm{t}$ value & coefficient & $\mathrm{t}$ value & coefficient & $\mathrm{t}$ value \\
\hline (Constant) & -0.011 & -0.200 & -0.039 & -0.766 & -0.015 & -0.280 \\
Fratio & $-0.001^{* *}$ & -2.473 & & & $-0.001^{* *}$ & -2.075 \\
Fem & & & $-0.058^{* * *}$ & -2.898 & $-0.052^{* * *}$ & -2.566 \\
CN & $0.001^{* *}$ & 2.108 & $0.001^{* *}$ & 2.059 & $0.001^{* *}$ & 2.143 \\
Outdir & $-0.002^{*}$ & -1.749 & $-0.002^{*}$ & -1.734 & $-0.001^{*}$ & -1.651 \\
Size & $0.009^{* *}$ & 2.046 & $0.010^{* *}$ & 2.266 & $0.009^{* *}$ & 2.043 \\
R & 0.119 & & 0.125 & & 0.137 & \\
F & 5.031 & & 5.608 & & 5.358 & 1409 \\
Sample size & 1409 & & 1409 & & & \\
\hline
\end{tabular}

Note: $* \mathrm{P}<0.1, \quad * * \mathrm{P}<0.05,{ }^{* * *} \mathrm{P}<0.01$

Table shows that the proportion of female executives has a significant negative correlation on the non-efficient investment $(\beta=-0.001, P<0.05)$. whether the $\mathrm{CEO}$ is female or not is significantly negatively correlated on the non-efficient investment $(\beta=-0.052, \mathrm{P}<0.01)$. Hypotheses 1 and 4 are supported.

In addition, we further examine the moderating effects of human capital and social capital on the proportion of female executives and corporate non-efficient investment in companies.Among them, Model II is a regression analysis of the moderating effect of human capital on the proportion of female executives and corporate non-efficient investment, and Model III is a regression analysis of the moderating effect of social capital on the proportion of female executives and corporate non-efficient investment.

Table 5.2. Regression analysis of the proportion of female executives, human capital, social capital and non-efficient investment

\begin{tabular}{lllll}
\hline & Model II & & Model III & \\
\cline { 2 - 5 } & coefficient & t value & coefficient & $\mathrm{t}$ value \\
\hline (Constant) & 0.053 & 0.928 & -0.009 & -0.179 \\
Fratio & $-0.001^{* *}$ & -2.546 & $-0.001^{*}$ & -1.651 \\
Hcap1 & $-0.023^{* *}$ & -2.875 & & \\
Fratio*Hcap1 & $-0.001^{*}$ & -1.656 & & \\
Scap1 & & & $-0.003^{*}$ & -1.850 \\
Fratio*Scap1 & & & $-0.045^{* * *}$ & -2.995 \\
CN & $0.001^{* *}$ & 2.029 & $0.001^{* *}$ & 2.022 \\
Outdir & $-0.002^{*}$ & -1.751 & $-0.002^{*}$ & -1.815 \\
Size & $0.011^{*}$ & 2.361 & $0.010^{* *}$ & 2.111 \\
R & 0.142 & & 0.170 & \\
F & 4.832 & & 6.921 & \\
Sample size & 1409 & & 1409 & \\
\hline
\end{tabular}

Note: $* \mathrm{P}<0.1, \quad * * \mathrm{P}<0.05, * * * \mathrm{P}<0.01$

Table 5-2 shows that the higher the average education level of senior executives and the higher the proportion of female senior executives, the lower the level of non-efficient investment $(\beta=-0.001, P<0.1)$. It indicates that human capital plays a regulating role in the proportion of female executives and the level of non-nefficient investment in companies, and significantly inhibits the non-efficient investment. So hypothesis 2 is supported.

the higher the social capital and the higher the proportion of female executives, the more non-efficient investment will be inhibited $(\beta=-0.045, \mathrm{P}<0.01)$. This is because, when the proportion of social capital is higher, it will play a more positive role in promoting the investment management of companies, and give full play to the supervisory functions of senior executives. Especially under the regulatory role of female senior executives, the significant impact on the inhibiting effect of non-efficient investment will be significantly increased. Therefore, hypothesis 3 is supported.

Next, we further examine the moderating effects of human capital and social capital on female CEO and enterprise non-efficient investment respectively. Among them, model IV is the regression analysis of the regulatory effect of human capital on female ceos and non-efficient investment in companies, and model $\mathrm{V}$ is the regression. analysis of the regulatory effect of social capital on female ceos and non-efficient investment in companies. 
Table 5.3. Regression analysis of female CEO, human capital, social capital and non-efficient investment

\begin{tabular}{lllll}
\hline & Model IV & & Model V & \\
\cline { 2 - 5 } & coefficient & $\mathrm{t}$ value & coefficient & $\mathrm{t}$ value \\
\hline (Constant) & 0.006 & 0.105 & -0.040 & -0.772 \\
Fem & $-0.060^{* * *}$ & -2.989 & $-0.056^{* *}$ & -2.479 \\
Hcap2 & $-0.014^{* *}$ & -2.422 & & \\
Fem*Hcap2 & $-0.042^{*}$ & -1.746 & & \\
Scap2 & & & -0.011 & -0.249 \\
Fem*Scap2 & & & -0.012 & -0.249 \\
CN & $0.001^{*}$ & 1.857 & $0.001^{* *}$ & 2.061 \\
Outdir & $-0.002^{*}$ & -1.684 & $-0.002^{*}$ & -1.724 \\
Size & $0.011^{* *}$ & 2.353 & $0.010^{* *}$ & 2.267 \\
R & 0.148 & & 0.126 & \\
F & 5.234 & & 4.496 & \\
Sample size & 1409 & & 1409 & \\
\hline
\end{tabular}

Note: $* \mathrm{P}<0.1, \quad * * \mathrm{P}<0.05, * * * \mathrm{P}<0.01$

It shows that the higher the education level is, the more significantly it can inhibit the non-efficient investment. The human capital plays a mediating effect in the influence of the female CEOs on the non-efficient investment, $(\beta=-0.042, \mathrm{P}<0.1)$, which supports H5. However, the gender of CEO does not significantly affect non-efficient investment under the regulatory role of social capital, so hypothesis 6 is refused.

\section{Conclusion and Recommendations}

\subsection{Conclusion}

This paper makes a comprehensive and detailed analysis on the leadership of non-efficient investment of female executives in private listed companies in Shanghai and Shenzhen. In order to ensure the scientific nature of the research and the robustness of the conclusions, this paper conducts a study from the perspectives of female executives and female CEOs, at the same time, the moderating effect of human capital and social capital on female executives and non-efficient investment behaviors of enterprises is considered comprehensively, financial data is used to show the leadership of female executives in corporate performance. Draw the following conclusions:

Both female executives and female CEOs can effectively curb non-efficient investment.

Female CEOs have a stronger influence on corporate non-efficiency investment than overall female executives. This shows that in private companies, the increase in the proportion of female CEOs relative to female executives can significantly inhibit non-efficient investment.

(1) This article further validates the moderating effect of human capital and social capital on female executives and female CEOs. The results show that the level of education has a significant moderating effect on both female executives and the non-efficient investment of female CEOs and companies.

(2) Social capital has a moderating effect on the non-efficient investment of female executives and enterprises, but has no significant effect on the gender of CEOs and non-efficient investment of enterprises.

\subsection{Recommendations}

Based on the findings, some recommendations for the organizations are suggested as follows:

(1) Build a diversified executive team

Companies should pay attention to the special advantage resources of female senior management, and bring the company's gender diversity management to the company's strategic level, especially in developing countries. Build a diversified senior management team, allow and increase women's participation in the senior management team.

(2) Establish an efficient senior management team.

Efficient senior management team can improve the performance of the enterprise. Because female executives play multiple roles in family and life, they are more amiable and cohesive, and thus easier to enhance the sense of belonging and responsibility of employees. This provides inspiration for the construction of senior management team in this paper. Female executives have keen observation skills, discover and deal with problems between team members in a timely and effective manner, communicate in a gentle way and deal with them in a timely manner, subordinates can also understand the company's trends and clarify the company's 
development direction, thereby giving employees a positive orientation. To achieve the interaction between the superior and the subordinate, improve the scientificity, rationality and effectiveness of decision-making.

(3) Increase human capital investment, optimize human capital structure.

Compared with state-owned companies, private companies have certain disadvantages in attracting talents. If private companies want to go further in the competition, on the one hand, strengthen the training of senior management, encourage in-service managers to improve their academic background, and continuously improve and improve their own knowledge level to adapt to the ever-changing external environment, or vigorously develop the "talent introduction" policy and introduce professional female managers with high academic backgrounds. On the other hand, private enterprises must ensure the standardization, system and fairness of the manager selection mechanism. Oppose cronyism and gender discrimination in the workplace. Enterprises should consciously look for those who fit the job position, put the right people in the right positions, make the best use of their talents, break the "ceiling" of the female workplace, and avoid the waste of human resources.

Rational development and utilization of social capital.

Most companies are "family-style" companies, which requires the company's managers not to be blindsided, but to recognize their own strengths and weaknesses. In the context of the Chinese market, "relationships" are extremely important. Managers possessing social capital can effectively improve the performance of enterprises. Social capital provides enterprises with relational resources. Executives can collect and organize more comprehensive information by integrating various social resources. Provide a basis for the decision-making of the enterprise, thereby reducing the transaction cost of the enterprise, and realizing the optimization of enterprise investment. However, the company must develop social capital rationally. Because managers with social capital are more convenient to obtain resources, and are more likely to breed overconfidence. If they are not oriented toward corporate value, they will inevitably waste resources. Optimize the capital structure, pay attention to the government experience of female executives when recruiting, so that the role of social capital can be fully and effectively played.

\subsection{Research Significance}

At present, the gender heterogeneity of executives has become one of the key areas that scholars at home and abroad pay attention to. Aiming at the current situation of non-efficient investment in listed companies in China, it is important to in-depth study of the relationship between female executive leadership and investment efficiency in companies. The academic value and practical significance of the company have not only enriched the characteristics of managers and the literature and empirical research in the field of corporate investment, but also provided reference for the further improvement of the capital structure decision-making, investment decision-making and human resource management practices of listed companies in China. The reform and development of listed companies and the entire capital market in the transformation process are of great significance.

\subsubsection{Theory Significance}

At present, among the researches on irrational investment of managers, the researches on the characteristics of executives and the overconfidence of managers are relatively common. But there are few studies on gender differences in executive traits. Therefore, this paper will discuss non-efficient investment behavior from the perspective of female executives on the basis of previous scholars. To further explore the mechanism and principle of many enterprises' non-efficient investment is an innovation of the research perspective, which can provide empirical basis for the research on corporate governance. It also shows that the gender of executives is an important factor to be considered when studying the governance effect of corporate executives on the investment efficiency of enterprises.

\subsubsection{Practical Significance}

At present, China is in the stage of economic transformation, and the political, economic and social environment is faced with uncertainties. There are also many uncertainties in the operation and management of enterprises attached to the environment. Compared with state-owned enterprises, private enterprises lack resources and access to resources. Influenced by social environment and personal characteristics, some executives rely on their own preferences or intuition when making investment decisions, leading to non-efficient investment behaviors. KevinC.K.Lam, PualB, etc. (2013) found that in China, especially in private enterprises, the proportion of women is rising. Therefore, in this context, studying the non-efficient investment of private listed companies from the perspective of female executives will help improve the corporate governance structure of private listed companies, and help avoid and curb over-investment and improve under-investment from the source of 
investment decisions The problem, which in turn provides a certain basis for improving operating efficiency and increasing corporate performance, has very important theoretical and far-reaching practical significance for promoting the long-term development of the enterprise and protecting the interests of the various stakeholders of the enterprise. It has certain enlightening significance to select private enterprises and restrain the irrational investment behavior of private listed companies.

\section{Limitations and Future Research}

This article about female executives focused on the efficiency of human capital, social capital and the enterprise the investment behavior of the micro research, for the environment of macro research for discussion, therefore, future research can be in the macro environment to discuss the influence on the efficiency of investment, establish contain macro micro dimensional model of affecting factors.

This article mainly choose education level of human capital as the inspection object, and the scope of social capital is mainly from the political association, political background, the measure of the human capital and social capital is not comprehensive, the future can be more comprehensive, at the same time, also can consider introducing psychological scale, from the aspects of psychological characteristics and other comprehensive consideration.

Cross-section data are selected in this paper. The investment of an enterprise may be a long-term process, so it may affect the analysis results to some extent. Moreover, the measurement of the inefficiency investment model in this article draws on foreign models. To a certain extent, Chinese enterprises are different from Western enterprises. Therefore, Future research can select companies in countries different from China as research objects and test the validity and universality of the research conclusions.

\section{References}

Appold, S. J., Siengthai, S., \& Kasarda, J. D. (1998). The employment of women managers and professionals in an emerging economy: gender inequality as an organizational practiced. Administrative Science Quarterly, 43(3), 538-655. https://doi.org/10.2307/2393675

Dai, M. X. (2010). Research on the Relationship between Overconfidence of Managers and non-efficient Investment. Dalian University of Technology.

Firth, M., Fung, P. M. Y., \& Rui, O. M. (2007). Ownership, two tier board structure, and the informativeness of earnings-Evidence from China. Journal of Accounting and public policy, 26(4), 463-496. https://doi.org/10.1016/j.jaccpubpol.2007.05.004

Grenadier, S. R., \& Wang, N. (2005). Investment Timing, Agency, and Information [J]. Journal of Financial Economics, 75(3), 493-533. https://doi.org/10.1016/j.jfineco.2004.02.004

Heaton, J. (2002). Managerial optimisn and corporate finance. Financial Management, 31(12), 33-45. https://doi.org/10.2307/3666221

Hillman, A. J., Shropshire, C., \& Cannella, J. A. (2007). Organizational Predictors of Women on Corporate Boards. Academy of Management Journal, 50(4), 941-952. https://doi.org/10.5465/amj.2007.26279222

Huang, J., \& Kisgen, D. J. (2013). Gender and corporate finance: Are male executives overconfident relative to female executives? Journal of Financial Economics, 108(3), 822-839. https://doi.org/10.1016/j.jfineco.2012.12.005

Jensen, M. C. (1986). Agency costs of free-cash-flow, corporate finance, and takeovers. American Economic Review, 76, 323-329.

Kevin, C. K. L., Paul, B. M., \& Joao, P. V. (2013). CEO gender, executive compensation and firm performance in Chinese-listed enterprises. Pacific-Basin Finance Journal, 21, 1136-1159. https://doi.org/10.1016/j.pacfin.2012.08.006

Lu, X., He, Y. Q., \& Wu, T. (2016). Is the political promotion of state-owned enterprise executives a long-term strategy? Economic Management, 7, 94-107.

Lu, X., Zhang, L. L., Li, H. M., \& Ding, Y. P. (2017).The background characteristics of top management team and investment efficiency. Audit and Economic Research, 2, 66-78.

Luca, F., \& Mario, M. (2013). Do Female Executives Make a Difference? The Impact of Female Leadership on Firm Performance and Gender Gaps in Wages and Promotions. Journal of Economic Behavior and Organization, 21, 1136-1159. 
Myers, S. C., \& Majluf, N. S. (1984). Corporate financing and investment decisions when firms have information that investors do not have. Social Science Electronic Publishing, 13(2), 187-221. https://doi.org/10.1016/0304-405X(84)90023-0

Pfeffer, J., \& Salancik, G. R. (1987). The External Control of Organizations: A Resource Dependence Perspective. NY: Harper \& Row.

Qin, Q. Q., \& Tan, W. Q. (2009). Market-oriented reform, enterprise performance and state-owned enterprise manager compensation. Economic Research, 11, 68-81.

Roll, R. (1986). The bubris hypothesis of corporate takeovers. Journal of Business, 59(5), 197-216. https://doi.org/10.1086/296325

Rosa, P., Carter, S., \&Hamilton, D. (1996). Gender as a Determinant of Small Business Performance: Insights from a British Study. Small Business Economics, 8, 463-78. https://doi.org/10.1007/BF00390031

Ross, S. A. (1973). The Economic Theory of Agency: The Principal's Problem. American Economic Review, 63(2), 134-139.

Welbourne, T. M. (1999). Wall Street Likes its Women: An Examination of Women in the Top Management Teams of Initial Public Offerings. Working Paper, Center for Advanced Human Resource Studies.

Wolosin, R. J., Sherman, S. J., \& Till, A. (1973). Effects of cooperation and competition on responsibility attribution after success and failure. Journal of experimental social psychology, 9(3), 220-235. https://doi.org/10.1016/0022-1031(73)90011-5

Xin, Q. Q., Lin, B., Wang, Y. C. (2007). Government control, executive compensation and capital investment. Economic Research Journal, 8, 110-123.

Yang, D., \& Wang, N. et al. (2011). Accounting conservatism and listed companies' investment behavior. Accounting Research, 3, 27-34.

Yang, R. (2009). A Review of Researches on the Correlation between Executive Overconfidence and Corporate Investment Decisions. China Collective Economy, 21, 82-87.

Zhang, Z. G., Liu, Y. W., \& Yuan, X. L. (2013). A study on the characteristics of managers' background, promotion incentive and overinvestment. Nankai Management Review, 4, 32-42.

Zhu, J. G., Ye, K. T., \&Yan, D. (2010). A study on risk aversion of female directors and corporate investment behavior from the perspective of financial crisis. Finance and Trade Economics, 04, 50-58.

Zuckerman, M. (1994). Behavioral expressions and biosocial bases of sensation seeking. Cambridge university pres. 


\section{Appendixes}

Table 4.1. Descriptive Statistics of Variables

\begin{tabular}{llllll}
\hline & & $\begin{array}{l}\text { Minimal } \\
\text { value }\end{array}$ & Maximal value & Mean value & Standard deviation \\
\hline Fratio & 1409 & $4.55 \%$ & $63.64 \%$ & $21.6250 \%$ & $10.20808 \%$ \\
Hcap1 & 1409 & 1 & 5 & 3.16 & 0.628 \\
Scap1 & 1409 & $0.00 \%$ & $20.00 \%$ & $1.5002 \%$ & $3.05175 \%$ \\
Fem & 1409 & 0 & 1 & 0.06 & 0.238 \\
Hcap2 & 1409 & 1 & 5 & 3.44 & 0.839 \\
Scap2 & 1409 & 0 & 1 & 0.01 & 0.118 \\
CN & 1409 & $4.15 \%$ & $79.28 \%$ & $30.7406 \%$ & $12.85750 \%$ \\
Outdir & 1409 & $30.00 \%$ & $60.00 \%$ & $37.7328 \%$ & $5.33191 \%$ \\
Size & 1409 & 3.81 & 11.53 & 7.55 & 1.04919 \\
Valid case & 1409 & & & & \\
\hline
\end{tabular}

Table 4.2. Descriptive Statistics of Sample Residuals

\begin{tabular}{crrrrr}
\hline & $\mathrm{N}$ & \multicolumn{1}{c}{ Minimal value } & Maximal value & Mean value & Standard deviation \\
\hline $\begin{array}{c}\text { I } \\
\text { vamber of }\end{array}$ & 1409 & -1.0378 & 1.6483 & 0.0000 & 0.1803 \\
valid cases & 1409 & & & & \\
\hline
\end{tabular}

\section{Copyrights}

Copyright for this article is retained by the author(s), with first publication rights granted to the journal.

This is an open-access article distributed under the terms and conditions of the Creative Commons Attribution license (http://creativecommons.org/licenses/by/4.0/). 